ISSN: 2302-8556

E-Jurnal Akuntansi Universitas Udayana

Vol.25.2.November (2018): 1448-1480

DOI: https://doi.org/10.24843/EJA.2018.v25.i02.p24

\title{
Pengaruh Etika Profesi Dan Keahlian Audit Pada Kinerja Auditor Dengan Skeptisisme Profesional Auditor Sebagai Variabel Mediasi
}

\author{
Ni Kadek Yunita Ardaleni ${ }^{1}$ \\ I D.G. Dharma Suputra ${ }^{2}$
}

\author{
${ }^{1,2}$ Fakultas Ekonomi dan Bisnis Universitas Udayana (Unud), Bali, Indonesia \\ email: lennyarda23@gmail.com/ Telp: 081353391682 \\ ${ }^{2}$ Fakultas Ekonomi dan Bisnis Universitas Udayana (Unud), Bali, Indonesia
}

\begin{abstract}
ABSTRAK
Tujuan penelitian ini untuk mengetahui pengaruh etika profesi dan keahlian audit pada kinerja auditor dengan skeptisisme profesional auditor sebagai variabel mediasi pada kantor Akuntan Publik di Provinsi Bali. Penelitian ini dilakukan pada kantor Akuntan Publik Provinsi Bali Penelitian ini dilakukan pada kantor Akuntan Publik Provinsi Bali dengan tujuh kantor pada tahun 2017 dengan jumlah auditor sebanyak 74 orang sebagai sampel melalui metode sample jenuh. Data dikumpulkan dengan menyebarkan kuesioner kepada 74 auditor, sebanyak 26 tidak dipergunakan karena tidak kembali sehingga 48 kuesioner yang memenuhi kriteria diolah melalui teknik analisis path (analisis jalur).Berdasarkan hasil analisis, variabel etika profesi berpengaruh positif dan signifikan pada kinerja auditor pada Kantor Akuntan Publik di Bali. Keahlian audit berpengaruh positif dan signifikan pada kinerja auditor pada Kantor Akuntan Publik di Bali. Skeptisisme profesional berpengaruh positif dan signifikan pada kinerja auditor pada Kantor Akuntan Publik di Bali. Skeptisisme profesional auditor memediasi pengaruh positif etika profesi pada kinerja auditor pada Kantor Akuntan Publik di Bali. Skeptisisme profesional auditor memediasi pengaruh positif keahlian audit pada kinerja auditor pada Kantor Akuntan Publik di Bali
\end{abstract}

Kata kunci: etika profesi, keahlian audit, skeptisisme profesional auditor, pada kinerja auditor

\begin{abstract}
The purpose of this study to determine the influence of professional ethics and audit expertise on the performance of auditors with professional skepticism of auditors as a mediation variable at the Public Accounting firm in Bali Province. This research was conducted at Public Accountant Office of Bali Province with seven offices in 2017 with 74 auditor number as sample through saturated sample method. Data collection was done by distributing questionnaires with 48 respondents who returned and 26 not used because of no return and 48 questionnaires that met the criteria through path analysis technique (path analysis). Based on the results of the analysis, professional ethics variables have positive and significant influence on the performance of auditors at Public Accounting Firm in Bali. Audit expertise has a positive and significant impact on the performance of auditors at Public Accounting Firm in Bali. Professional skepticism has a positive and significant influence on the performance of auditors at Public Accounting Firm in Bali. Professional auditor skepticism mediates the positive effect of professional ethics on the performance of auditors at Public Accounting Firm in Bali. Professional auditor skepticism mediates the positive influence of audit expertise on auditor performance at Public Accounting Firm in Bali
\end{abstract}

Keywords: professional ethics, audit expertise, professional skepticism of auditors, on auditor performance. 


\section{PENDAHULUAN}

Peran auditor telah menjadi pusat kajian dan riset di kalangan akademisi. Tidak hanya itu, praktisi juga semakin kritis dengan selalu menganalisa kontribusi apa yang diberikan auditor. Menurut SPAP PSA No.02 SA Seksi 110 (SPAP, 2011) menyatakan "tujuan audit atas laporan keuangan oleh auditor independen pada umumnya adalah untuk menyatakan pendapat tentang kewajaran, dalam semua hal yang material, posisi keuangan, hasil usaha, perubahan ekuitas, dan arus kas sesuai dengan Standar Akuntansi Keuangan di Indonesia. Peran dan Profesi akuntan publik merupakan profesi kepercayaan yang diberikan masyarakat untuk mutu jasa auditor (Alnoprika, 2015).

Tantangan profesi akuntansi semakin pesat dengan diberlakukannya Masyarakat Ekonomi Asean (MEA) pada tahun 2015. Akuntan Indonesia harus menghadapi persaingan dengan akuntan asing untuk menawarkan jasa profesinya. Pemerintah Indonesia bersama dengan seluruh anggota Negara-negara Asia Tenggara yang tergabung dalam Asean sudah menyepakati pemberlakukan Masyarakat Ekonomi Asean (MEA) pada tahun 2015. Salah satu bidang jasa yang diberlakukan secara bebas adalah jasa profesi akuntansi, untuk itu pemerintah telah menyiapkan berbagai perangkat peraturan untuk menjamin adanya persiangan yang sehat dalam penyediaan jasa profesi akuntansi. Pemberlakuan Masyarakat Ekonomi Asean (MEA) juga memberikan konsekuensi positif maupun negatif bagi profesi akuntan di Indonesia (Feibe et al., 2016). 
ISSN: 2302-8556

E-Jurnal Akuntansi Universitas Udayana

Vol.25.2.November (2018): 1448-1480

Auditing adalah pengumpulan dan evaluasi bukti tentang informasi untuk menentukan dan melaporkan derajat kesesuaian antara informasi itu dan kriteria yang telah ditetapkan (Meylinda dan Budiartha, 2015). Tujuan akhir dari proses auditing ini adalah menghasilkan laporan audit, laporan audit inilah yang digunakan oleh auditor untuk menyampaikan pernyataan atau pendapatnya kepada para pemakai laporan keuangan, sehingga bisa dijadikan acuan bagi pemakai laporan keuangan (Nila, 2014). Agar tujuan tersebut tercapai maka kinerja seorang akuntan publik dalam menjalankan profesinya harus mengacu pada standar yang telah ditetapkan yaitu Standar Profesional Akuntan Publik (SPAP) dari Ikatan Akuntan Publik Indonesia (IAPI). Pemenuhan standar audit oleh auditor dapat berdampak pada peningkatan hasil auditnya, yaitu dengan hasil kinerja yang maksimal (Riris dan Lenny, 2016). Seorang akuntan publik yang profesional dapat dilihat dari hasil kinerja auditor dalam menjalankan tugas dan fungsinya. Untuk menghasilkan kinerja yang memuaskan seorang auditor harus memiliki sikap yang jujur atau independen dalam melaporkan hasil audit terhadap laporan keuangan (Putri dan Dharma, 2013).

Istilah kinerja digunakan untuk menyebutkan prestasi atau tingkat keberhasilan individu atau kelompok individu (Lismawati, 2014). Kinerja yang baik tentunya tidak terbentuk begitu saja, namun ditentukan oleh banyak faktor. Satwika dan Ramantha (2015) mengemukakan kinerja auditor merupakan aktivitas penilaian independent yang dibentuk dalam rangka menguji dan mengevaluasi kegiatan-kegiatan perusahaan yang bertujuan membantu anggota perusahaan agar dapat menyelesaikan tanggungjawabnya secara efektif dan karena tujuan tersebut auditor memiliki 
tanggung jawab untuk merencanakan dan melaksanakan audit agar memperoleh keyakinan memadai bahwa manajemen menjalankan operasional perusahan dengan baik dan memenuhi kriteria yang telah ditetapkan dan mendeteksi penipuan atau kecurangan dan memelihara pengendalian perusahaan (Rita et al., 2011).

Kinerja auditor merupakan tindakan atau pelaksanaan tugas pemeriksaan yang telah diselesaikan oleh auditor dalam kurun waktu tertentu. Hal ini ditujukan untuk menjamin bahwa pelaksanaan kegiatan telah sesuai dengan kebijakan dan rencana yang telah ditetapkan serta untuk menjamin bahwa tujuan tercapai secara ekonomis, efisien dan efektif dalam pencapaian hasil yang diinginkan dan kepatuhan terhadap kebijakan, peraturan dan hukum yang berlaku (Azza and Zhou, 2010). Mereka juga menilai apakah laporan keuangan organisasi disajikan sesuai dengan prinsip-prinsip akuntansi yang diterima secara umum, diterapkan secara konsisten dari periode ke periode, dan seterusnya (Riris, 2016). Begitu pentingnya kinerja seorang auditor bagi klien, maka seorang auditor harus mempunyai keahlian dan kompetensi yang baik untuk mengumpulkan dan menganalisa bukti-bukti audit (Bariyima dan David, 2012). Auditor dituntut untuk melaksanakan skeptisisme profesionalnya sehingga auditor dapat menggunakan kemahiran profesionalnya dengan cermat dan seksama, karena kemahiran profesional seorang auditor mempengaruhi kinerjanya (Luz, 2012).

Yulia dan Dharma (2017) menyatakan hal dasar yang harus diperhatikan oleh auditor adalah etika dalam berprofesi. Pelaksanaan pekerjaan profesional tidak lepas dari etika karena perilaku professional diperlukan bagi semua profesi agar profesi yang dijalaninya mendapat kepercayaan dari masyarakat dengan kesadaran etis yang 
ISSN: 2302-8556

E-Jurnal Akuntansi Universitas Udayana

Vol.25.2.November (2018): 1448-1480

tinggi, maka seorang auditor cenderung profesional dalam tugasnya dan menjalankan tugasnya sesuai dengan kode etik profesi dan standar auditing, sehingga hasil audit yang dilakukan akan lebih menunjukkan keadaan yang sebenarnya. Sukendra et al. (2015) menjelaskan The American Heritage Directory yang menyatakan etika sebagai suatu aturan atau standar yang menentukan tingkah laku para anggota dari suatu profesi. Melalui kesadaran etis yang tinggi, maka seorang auditor cenderung profesional dalam tugasnya dan menjalankan tugasnya sesuai dengan kode etik profesi dan standar auditing, sehingga hasil audit yang dilakukan akan lebih menunjukkan keadaan yang sebenarnya. Beberapa penelitian dimana Ratna (2016) etika memiliki pengaruh positif terhadap kinerja auditor. Nila (2014) variabel etika profesi memiliki pengaruh positif terhadap kinerja auditor. Riris dan Lenny, (2016) membuktikan hal yang sama dimana etika profesi memberikan pengaruh positif pada kinerja auditor. Berbeda dengan penelitian Bariyima and David (2012) etika profesi secara parsial tidak berpengaruh terhadap kinerja auditor. Penelitian Eluyela and Ilogho (2016) dalam standar audit etika tidak memberikan pengaruh terhadap kinerja auditor.

Faktor lain yang dapat mempengaruhi kinerja seorang audit adalah keahlian, dimana keahlian meliputi keahlian dalam melakukan pemeriksaan maupun penugasan masalah yang sedang diperiksanya. Keahlian adalah auditor yang mempunyai pengalaman yang cukup untuk melakukan audit secara objektif, cermat dan seksama (Tresno and Irene, 2016). Keahlian seorang auditor di dalam menjalankan tugas profesionalismenya akan mempengaruhi tingkat kualitas audit yang baik, begitu juga 
sebaliknya bila keahlian rendah atau buruk maka kualitas audit yang dihasilkan rendah. Syamsuddin et al. (2014) mendifinisikan keahlian sebagai keberadaan dari pengetahuan tentang suatu lingkungan tertentu, pemahaman terhadap masalah yang timbul dalam lingkungan tersebut, dan keterampilan untuk memecahkan masalah tersebut. Ikatan Akuntansi Indonesia (2001) menjelaskan auditor dapat mencapai keahlian melalui pendidikan formal dan praktik audit, selain itu auditor harus menjalani pelatihan teknis maupun pendidikan umum. Penelitian mengenai pengaruh keahlian terhadap kualitas audit telah dilakukan oleh Lisnawati (2014), dimana dalam penelitiannya membuktikan bahwa keahlian berpengaruh signifikan terhadap kinerja auditor. Penelitian Ratna (2016) keahlian memiliki pengaruh positif terhadap kinerja auditor. Tae et al. (2014) variabel keahlian memiliki pengaruh positif terhadap kinerja auditor. Takiah and Zuraidah (2011) membuktikan hal yang sama dimana keahlian memberikan pengaruh positif pada kinerja auditor. Berbeda dengan penelitian Feibe et al. (2016) keahlian secara parsial tidak berpengaruh terhadap kinerja auditor. Penelitian Musa and Shehu (2014) keahlian tidak memberikan pengaruh terhadap kinerja auditor.

Auditor dituntut untuk melaksanakan skeptisisme profesionalnya sehingga auditor dapat menggunakan kemahiran profesionalnya dengan cermat dan seksama, karena kemahiran profesional seorang auditor mempengaruhi ketepatan opini yang diberikannya (Luz, 2012). Sehingga tujuan auditor untuk memperoleh bukti kompeten yang cukup dan memberikan basis yang memadai dalam merumuskan pendapat dapat memberikan hasil kinerja yang maksimal. Beberapa penelitian dimana 
ISSN: 2302-8556

E-Jurnal Akuntansi Universitas Udayana

Vol.25.2.November (2018): 1448-1480

Steven and Douglas (2014) skeptisisme memiliki pengaruh positif terhadap kinerja auditor. Tae et al. (2014) variabel skeptisisme professional mampu memperkuat hubungan keahlian terhadap kinerja auditor. Pandoyo (2016) membuktikan skeptisisme professional memoderasi pengaruh etika profesi pada kinerja auditor. Berbeda dengan penelitian Ohiokha \& Akhalumeh (2013) skeptisisme professional tidak memoderasi pengaruh keahlian pada kinerja auditor. Penelitian Riris dan Lenny (2016) skeptisisme professional tidak memperkuat hubungan etika profesi pada kinerja auditor.

Dalam pelaksanaan pemeriksaan akuntansi oleh auditor harus berdasarkan pada prinsip akuntansi yang berlaku umum dan selalu menegakkan kode etik profesi sebagai akuntan publik (IAPI, 2010). Profesi akuntansi merupakan sebuah profesi yang menyediakan jasa atestasi maupun non atestasi kepada masyarakat dengan dibatasi kode etik yang ada. Etika dibutuhkan untuk bisa menghasilkan kinerja yang baik (Emrinaldi et al., 2014). Etika yang terjalin diantara anggota tim audit menjadi aktivitas yang sangat fundamental untuk mencapai hasil akhir audit. Istilah profesional berarti tanggung jawab untuk berperilaku lebih dari sekadar memenuhi tanggung jawab secara individu dan ketentuan dalam peraturan dan hukum di masyarakat. Seorang akuntan publik, sebagai seorang profesional, harus menyadari adanya tanggung jawab pada publik, pada klien dan pada sesama rekan praktisi (Nila, 2014).

Oleh karena itu, jika auditor dapat menjaga keselarasan dalam etika profesinya, ia akan dapat melaksanakan auditnya dengan baik sesuai yang diharuskan dalam kode 
etik profesi (Emrinaldi et al., 2014). Ratna (2016) etika memiliki pengaruh positif terhadap kinerja auditor. Nila (2014) variabel etika profesi memiliki pengaruh positif terhadap kinerja auditor. Riris dan Lenny (2016) membuktikan hal yang sama dimana etika profesi memberikan pengaruh positif pada kinerja auditor. Atas dasar argumentasi ilmiah tersebut di atas, maka hipotesis yang dapat dirumuskan hasil penelitian sebagai berikut.

$\mathrm{H}_{1}$ : etika profesi berpengaruh positif pada kinerja auditor

Sukendra et al. (2015) menyatakan teori atribusi dipandang sebagai teori yang dapat mendasari untuk menjelaskan keahlian. Teori tersebut menyatakan, bahwa perilaku ditentukan untuk apa orang-orang ingin lakukan (sikap), apa yang mereka pikirkan akan mereka lakukan (aturan-aturan sosial), apa yang mereka bisa lakukan (kebiasaan), dan dengan konsekuensi perilaku yang mereka pikirkan. Sikap dan prilaku seorang auditor yang mempunyai keahlian khusus seperti pengetahuan, ketrampilan, dan kompetensi teknis lainnya yang diperlukan untuk melaksanakan tugas dan tanggungjawabnya sebagai auditor yang memiliki kinerja yang berkualitas.

Kinerja seorang audit dipengaruhi oleh keahlian yang dimiliki, semakin luas keahlian seorang auditor maka akan memberikan keyakinan bahwa hasil audit yang lebih baik (Yulia dan Dharma, 2017). Ratna (2016) keahlian memiliki pengaruh positif terhadap kinerja auditor. Tae et al. (2014) variabel keahlian memiliki pengaruh positif terhadap kinerja auditor. Takiah and Zuraidah (2011) membuktikan hal yang sama dimana keahlian memberikan pengaruh positif pada kinerja auditor. 
ISSN: 2302-8556

E-Jurnal Akuntansi Universitas Udayana

Vol.25.2.November (2018): 1448-1480

Berdasarkan uraian diatas, Maka hipotesis yang dapat dirumuskan dalam penelitian sebagai berikut.

$\mathrm{H}_{2}$ : keahlian audit berpengaruh positif pada kinerja auditor.

Menurut Agus (2014) menyebutkan adanya hubungan antara skeptisisme profesional auditor dengan kinerja auditor. Teori auditing yang dikemukakan oleh Mautz dan Sharaf (1961) dalam Agus (2014) menjelaskan bahwa seorang auditor harus memiliki sifat kehati-hatian dalam proses pemeriksaannya dan selalu mengindahkan norma-norma profesi dan norma moral yang berlaku. Sedangkan menurut Kamus Besar Bahasa Indonesia (2008) skeptisisme diartikan sebagai sikap atau paham yang memandang sesuatu hal dengan tidak pasti, sehingga seolah-olah bersifat kurang percaya ataupun ragu-ragu terhadap hal yang sedang dijalankan.

Adnyani et al. (2014) dalam penelitiannya menyatakan skeptisisme profesional memiliki peran penting di dalam meningkatkan kinerja auditor. Tae et al. (2014) variabel skeptisisme professional memiliki pengaruh terhadap kinerja auditor. Pandoyo (2016) membuktikan skeptisisme professional berpengaruh positif dalam meningkatkan kinerja auditor. Berbeda dengan penelitian Ohiokha \& Akhalumeh (2013) skeptisisme professional memiliki pengaruh pada kinerja auditor. Berdasarkan uraian diatas, maka hipotesis yang dapat dirumuskan hasil penelitian sebagai berikut. $\mathrm{H}_{3}$ : skeptisisme profesional berpengaruh positif pada kinerja auditor

Mautz dan Sharaf (1961) dalam Agus (2014) menjelaskan teori atribusi menyangkut cara kerja seorang auditor diharuskan memiliki sifat kehati-hatian dalam proses pemeriksaannya dan selalu mengutamakan etika profesi, sehingga berperan 
untuk meningkatkan kinerja seorang auditor. Adnyani et al. (2014) menjelaskan sikap skeptisisme profesional terhadap kinerja auditor dalam memberikan hasil informasi yang lebih banyak dan lebih signifikan daripada auditor yang memiliki tingkat skeptisisme profesional yang rendah, dan hal ini mengakibatkan auditor memiliki skeptisisme profesional yang tinggi akan lebih dapat mendeteksi adanya fraud karena informasi yang mereka miliki tersebut. Steven and Douglas (2014) skeptisisme memperkuat pengaruh positif etika profesi pada kinerja auditor. Pandoyo (2016) membuktikan skeptisisme professional memoderasi pengaruh etika profesi pada kinerja auditor. Riris dan Lenny, (2016) membuktikan hal yang sama dimana etika profesi memberikan pengaruh positif pada kinerja auditor dengan moderasi skeptisisme professional. Berdasarkan uraian diatas, maka hipotesis yang dapat dirumuskan hasil penelitian sebagai berikut.

$\mathrm{H}_{4}$ : Skeptisisme profesional memediasi pengaruh positif etika profesi pada kinerja auditor.

Seorang auditor harus cukup qualified untuk memberikan opini terhadap kewajaran sebuah laporan keuangan, seorang auditor harus memiliki etika serta keahlian untuk bisa memutuskan atau menentukan sejauhmana tingkat keakuratan dan kebenaran atas bukti-bukti maupun informasi dari klien, dengan tidak mengesampingkan sikap skpetisisme terhadap bukti-bukti hasil audit (Feibe et al., 2016). Penelitian Ratna (2016) keahlian memiliki pengaruh positif terhadap kinerja auditor melalui skeptisisme professional. Tae et al. (2014) variabel skeptisisme professional memperkuat hubungan keahlian terhadap kinerja auditor. Takiah and 
ISSN: 2302-8556

E-Jurnal Akuntansi Universitas Udayana

Vol.25.2.November (2018): 1448-1480

Zuraidah (2011) membuktikan hal yang sama dimana skeptisisme professional memoderasi variabel keahlian secara positif pada kinerja auditor. Berdasarkan uraian diatas, maka hipotesis yang dapat dirumuskan hasil penelitian sebagai berikut.

$\mathrm{H}_{5}$ : skeptisisme profesional memediasi pengaruh positif keahlian audit pada kinerja auditor.

\section{METODE PENELITIAN}

Penelitian ini adalah penelitian asosiatif dimana penelitian yang bertujuan untuk mengetahui hubungan dari variabel atau lebih. Variabel yang digunakan dalam penelitian ini adalah Variabel Bebas terdiri dari Etika Profesi dan Keahlian Audit, Variabel Mediasi, yaitu Skeptisme Professional, dan Variabel Terikat, yaitu Kinerja. Sampel yang digunakan dalam penelitian ini diambil dengan menggunakan Metode Sampel jenuh. Sampel Jenuh adalah teknik penentuan sampel apabila semua anggota populasi digunakan sebagai sampel (Sugiyono, 2013: 68). Pemilihan sampel ini telah mewakili populasi, dengan batas minimum sampel suatu penelitian adalah sebanyak 30 sampel. Jumlah responden yang akan dilibatkan sebagai sampel dalam penelitian ini adalah sebanyak 74 responden dengan menggunakan metode sensus (Sugiyono, 2013:17).

Teknik analisis data yang digunakan pada penelitian ini adalah analisis jalur (path analysis). Analisis jalur merupakan perluasan dari analisis regresi linier berganda, untuk menaksir hubungan kausalitas antar variabel yang berjenjang berdasarkan teori (Utama, 2009:135) 


\section{HASIL DAN PEMBAHASAN}

Statistik deskriptif menyajikan informasi mengenai karakteristik variabel-variabel penelitian yaitu jumlah amatan, nilai minimum, nilai maksimum, nilai mean, dan standar deviasi. Untuk mengukur nilai sentral dari distribusi data dapat dilakukan dengan pengukuran rata-rata (mean) sedangkan standar deviasi merupakan perbedaan nilai data yang diteliti dengan nilai rata-ratanya. Hasil statistik deskriptif dapat dilihat pada Tabel 1.

Tabel 1.

Hasil Statistik Deskriptif

\begin{tabular}{llllll}
\hline \multicolumn{1}{c}{ Variabel } & N & Min. & Max. & Mean & $\begin{array}{l}\text { Std. } \\
\text { Deviasi }\end{array}$ \\
\hline Etika profesi & 8 & 13 & 24 & 19,44 & 3,626 \\
Keahlian audit & 8 & 13 & 25 & 19,71 & 3,142 \\
Skeptisisme profesional & 8 & 8 & 15 & 12,06 & 2,067 \\
Kinerja auditor & 8 & 15 & 29 & 23,85 & 3,876 \\
\hline
\end{tabular}

Sumber: Data diolah, 2017

Tabel 1. dapat dilihat bahwa variabel etika profesi $\left(\mathrm{X}_{1}\right)$ memiliki nilai minimum sebesar 13, nilai maksimum sebesar 24, mean sebesar 19,44, dan standar deviasi sebesar 3,626. Ini berarti bahwa terjadi perbedaan nilai etika profesi yang diteliti terhadap nilai rata-ratanya sebesar 3,626.

Variabel keahlian audit $\left(\mathrm{X}_{2}\right)$ memiliki nilai minimum sebesar 13, nilai maksimum sebesar 25, mean sebesar 19,71, dan standar deviasi sebesar 3,142. Ini berarti bahwa terjadi perbedaan nilai keahlian audit yang diteliti terhadap nilai rataratanya sebesar 3,142 . 
ISSN: 2302-8556

Variabel skeptisisme profesional (M) memiliki nilai minimum sebesar 8, nilai maksimum sebesar 15, mean sebesar 12,06, dan standar deviasi sebesar 2,067. Ini berarti bahwa terjadi perbedaan nilai skeptisisme profesional yang diteliti terhadap nilai rata-ratanya sebesar 2,067.

Variabel kinerja auditor (Y) memiliki nilai minimum sebesar 15, nilai maksimum sebesar 29, mean sebesar 23,85, dan standar deviasi sebesar 3,876. Ini berarti bahwa terjadi perbedaan nilai perilaku disfungsional auditor yang diteliti terhadap nilai rata-ratanya sebesar 3,876. 
Tabel 2.

Hasil Uji Validitas

\begin{tabular}{ccc}
\hline Variabel & Instrumen & Pearson Correlation \\
\hline \multirow{2}{*}{ Etika profesi $\left(\mathrm{X}_{1}\right)$} & $\mathrm{X}_{1.1}$ & 0,732 \\
& $\mathrm{X}_{1.2}$ & 0,669 \\
& $\mathrm{X}_{1.3}$ & 0,778 \\
& $\mathrm{X}_{1.4}$ & 0,742 \\
$\mathrm{X}_{1.5}$ & 0,782 \\
& $\mathrm{X}_{2.1}$ & 0,798 \\
& $\mathrm{X}_{2.2}$ & 0,779 \\
Keahlian auditor $\left(\mathrm{X}_{2}\right)$ & $\mathrm{X}_{2.3}$ & 0,540 \\
& $\mathrm{X}_{2.4}$ & 0,799 \\
& $\mathrm{X}_{2.5}$ & 0,715 \\
& $\mathrm{M}_{.1}$ & 0,711 \\
& $\mathrm{M}_{.2}$ & 0,753 \\
& $\mathrm{M}_{.3}$ & 0,847 \\
& $\mathrm{Y}_{.1}$ & 0,755 \\
& $\mathrm{Y}_{.2}$ & 0,549 \\
& $\mathrm{Y}_{.3}$ & 0,752 \\
& $\mathrm{Y}_{.4}$ & 0,677 \\
& $\mathrm{Y}_{.5}$ & 0,632 \\
& $\mathrm{Y}_{.6}$ & 0,881 \\
\hline & &
\end{tabular}

Sumber: Data diolah, 2017

Tabel 2 diatas terlihat variabel etika profesi memiliki pearson correlation dari $0,669-0,782(>0,30)$, hal ini berarti bahwa pernyataan tersebut valid. Variabel keahlian audit memiliki pearson correlation dari $0,540-0,799(>0,30)$, hal ini berarti bahwa pernyataan tersebut valid. Variabel skeptisisme profesional memiliki pearson correlation dari $0,753-0,847(>0,30)$, hal ini berarti bahwa pernyataan 
ISSN: 2302-8556

E-Jurnal Akuntansi Universitas Udayana

Vol.25.2.November (2018): 1448-1480

tersebut juga valid. Variabel kinerja auditor memiliki pearson correlation dari 0,549

$-0,881(>0,30)$, hal ini berarti bahwa pernyataan dalam kuesioner adalah valid.

Tabel 3.

Hasil Uji Reliabilitas

\begin{tabular}{lc}
\hline \multicolumn{1}{c}{ Variabel } & $\begin{array}{c}\text { Cronbach's } \\
\text { Alpha }\end{array}$ \\
\hline Etika profesi $\left(\mathrm{X}_{1}\right)$ & 0,785 \\
Keahlian audit $\left(\mathrm{X}_{2}\right)$ & 0,780 \\
Skeptisisme profesional $(\mathrm{M})$ & 0,657 \\
Kinerja auditor $(\mathrm{Y})$ & 0,789 \\
\hline
\end{tabular}

Sumber: Data diolah, 2017

Tabel 3. menjelaskan bahwa nilai alpha di hitung masing-masing variabel lebih besar dari $\mathrm{R}$ alpha tabel yaitu 0,60 sehingga dapat disimpulkan bahwa pernyataan dalam kuesioner tersebut reliabel.

Uji normalitas ini dilakukan untuk menguji apakah dalam sebuah model regresi (variabel dependen dan variabel independen ataupun keduanya) memiliki distribusi normal atau tidak. Pengujian normalitas nilai residual dalam penelitian ini dilakukan dengan menggunakan metode Kolmogorov-Smirnov. Data dikatakan berdistribusi normal jika taraf signifikansi lebih besar dari 0,05. Dari uji normalitas didapatkan nilai signifikansi sebesar $0,536(0,536>0,05)$. Hal ini berarti model regresi berdistribusi normal.

Uji multikolinearitas digunakan untuk menguji apakah dalam model regresi ditemukan adanya korelasi antar variabel bebas. Jika nilai toleransi lebih dari 10 persen atau VIF kurang dari 10 maka dikatakan tidak ada multikolinearitas. Hasil dari Uji multikolinearitas didapatkan bahwa nilai tolerence masing-masing variabel lebih 
besar dari 0,1 dan nilai VIF lebih kecil dari 10, sehingga dapat disimpulkan bahwa dalam model regresi tidak terjadi multikolinearitas dan dapat digunakan dalam penelitian.

Uji heteroskedastisitas bertujuan untuk menguji apakah model regresi terjadi ketidaksamaan varians dari residual pengamatan ke pengamatan yang lain. Jika tingkat signifikansi berada di atas 0,05 maka model regresi ini bebas dari masalah heteroskedastisitas. Hasil dari Uji heteroskedastisitas didapatkan bahwa nilai sig. masing-masing variabel lebih besar dari 0,05 yang berarti variabel tersebut bebas heteroskedastisitas.

\section{Tabel 4.}

Rekapitulasi Hasil Regresi Struktur 1

\begin{tabular}{lllll}
\hline \multicolumn{1}{c}{ Model } & $\begin{array}{l}\text { Standardized } \\
\text { Coefficients } \\
\text { Beta }\end{array}$ & T & & Sig. \\
\hline (Constant) & & 0.459 & 0.640 & 0.526 \\
Etika Profesi & & 0.268 & 4.416 & 0.000 \\
Keahlian audit & 0.325 & 6.173 & 0.000 \\
$\mathrm{R}^{2} \quad: 0,866$ & & & \\
F Statistik : 145,806 & & & \\
Sig.F : 0,000 & & & \\
\hline
\end{tabular}

Sumber: Data diolah, 2017

Berdasarkan laporan pada Tabel 4, maka persamaan strukturalnya adalah sebagai berikut:

$$
\mathrm{M}=0.459 \mathrm{X}_{1}+0.268 \mathrm{X}_{2}+\mathrm{e} 1
$$

Berdasarkan Tabel 4.11 diperoleh nilai standar eror sebagai berikut:

$$
\begin{aligned}
& \mathrm{Pe}_{\mathrm{i}}=\sqrt{\left(1-R_{1}^{2}\right)} \\
& \mathrm{Pe}_{1}=\sqrt{\left(1-R_{1}^{2}\right)}=\sqrt{1-0,866}=0,366
\end{aligned}
$$


ISSN: 2302-8556

E-Jurnal Akuntansi Universitas Udayana

Vol.25.2.November (2018): 1448-1480

Tabel 4 menjelaskan hasil pengujian pengaruh variabel etika profesi $\left(\mathrm{X}_{1}\right)$ dan keahlian audit $\left(\mathrm{X}_{2}\right)$ terhadap skeptisisme profesional auditor $(\mathrm{M})$ dijelaskan bahwa etika profesi berpengaruh positif signifikan terhadap skeptisisme profesional auditor dengan nilai standardized coefficients beta sebesar 0,459 dan nilai sig t sebesar 0,000 $<0,05$, oleh karena nilai standardized coefficients beta sebesar 0,459 dengan nilai sig $\mathrm{t}=0,000$ maka $\mathrm{H}_{0}$ diterima. Hal ini berarti variabel etika profesi berpengaruh positif dan signifikan secara parsial terhadap skeptisisme profesional auditor pada Kantor Akuntan Publik Di Bali.

Keahlian audit berpengaruh positif signifikan terhadap skeptisisme profesional auditor dengan nilai standardized coefficients beta sebesar 0,268 dan nilai sig $\mathrm{t}$ sebesar $0,000<0,05$, oleh karena nilai standardized coefficients beta sebesar 0,268 dengan nilai sig $\mathrm{t}=0,000$ maka $\mathrm{H}_{0}$ diterima. Hal ini berarti variabel keahlian audit berpengaruh positif dan signifikan secara parsial terhadap skeptisisme profesional auditor pada Kantor Akuntan Publik Di Bali.

Tabel 5. Rekapitulasi Hasil Regresi Struktur 2

\begin{tabular}{llcccc}
\hline & Model & $\begin{array}{c}\text { Standardized } \\
\text { Coefficients }\end{array}$ & & & \\
& Beta & & T & & Sig. \\
\hline (Constant) & 0.658 & 0.779 & 0.440 & \\
Etika Profesi & 0.398 & 4.681 & 0.000 & \\
Keahlian auditor & 0.224 & 2.672 & 0.011 & \\
Skeptisisme profesional & $: 0,949$ & 0.912 & 5.226 & 0.000 & \\
$\mathrm{R}^{2}$ & & & & \\
F Statistik $\quad: 273,374$ & & & & \\
Sig.F & $: 0,000$ & & & &
\end{tabular}

Sumber: Data diolah, 2017 
Berdasarkan laporan pada Tabel 5, maka persamaan strukturalnya adalah sebagai berikut:

$\mathrm{Y}=0.398 \mathrm{X}_{1}+0.224 \mathrm{X}_{2}+912 \mathrm{M}+\mathrm{e}_{2}$

Berdasarkan Tabel 4.12 diperoleh nilai standar eror sebagai berikut :

$$
\begin{aligned}
& \mathrm{Pe}_{\mathrm{i}}=\sqrt{\left(1-R_{1}^{2}\right)} \\
& \mathrm{Pe}_{2}=\sqrt{\left(1-R_{1}^{2}\right)}=\sqrt{1-0,949}=0,225
\end{aligned}
$$

Tabel 5 menjelaskan hasil pengujian pengaruh variabel etika profesi $\left(\mathrm{X}_{1}\right)$, keahlian audit $\left(\mathrm{X}_{2}\right)$ dan skeptisisme profesional auditor $(\mathrm{M})$ terhadap kualitas audit (Y) dijelaskan bahwa etika profesi berpengaruh positif signifikan terhadap kualitas audit dengan nilai standardized coefficients beta sebesar 0,398 dan nilai sig t sebesar $0,000<0,05$, oleh karena nilai standardized coefficients beta sebesar 0,398 dengan nilai sig $\mathrm{t}=0,000$ maka $\mathrm{H}_{0}$ diterima. Hal ini berarti variabel etika profesi berpengaruh positif dan signifikan secara parsial terhadap kualitas audit pada Kantor Akuntan Publik Di Bali.

Keahlian audit berpengaruh positif signifikan terhadap skeptisisme profesional auditor dengan nilai standardized coefficients beta sebesar 0,224 dan nilai sig $\mathrm{t}$ sebesar $0,011<0,05$, oleh karena nilai standardized coefficients beta sebesar 0,224 dengan nilai sig $\mathrm{t}=0$,011 maka $\mathrm{H}_{0}$ diterima. Hal ini berarti variabel keahlian audit berpengaruh positif dan signifikan secara parsial terhadap kualitas audit pada Kantor Akuntan Publik Di Bali. 
ISSN: 2302-8556

E-Jurnal Akuntansi Universitas Udayana

Vol.25.2.November (2018): 1448-1480

Skeptisisme profesional auditor berpengaruh negatif terhadap perilaku disfungsional auditor dengan nilai standardized coefficients beta sebesar 0,912 dan nilai sig $\mathrm{t}$ sebesar $0,000<0,05$, oleh karena nilai standardized coefficients beta sebesar 0,912 dengan nilai sig $\mathrm{t}=0,000$ maka $\mathrm{H}_{0}$ ditolak. Hal ini berarti variabel skeptisisme profesional auditor berpengaruh positif secara parsial terhadap kualitas audit pada Kantor Akuntan Publik Di Bali.

Output hasil SPSS pengujian pengaruh variabel etika profesi $\left(\mathrm{X}_{1}\right)$ dan keahlian audit $\left(\mathrm{X}_{2}\right)$ terhadap kinerja auditor $(\mathrm{Y})$ dengan mediasi skeptisisme professional auditor (M) digambarkan dengan model diagram jalur seperti pada Gambar 4.2 berikut.

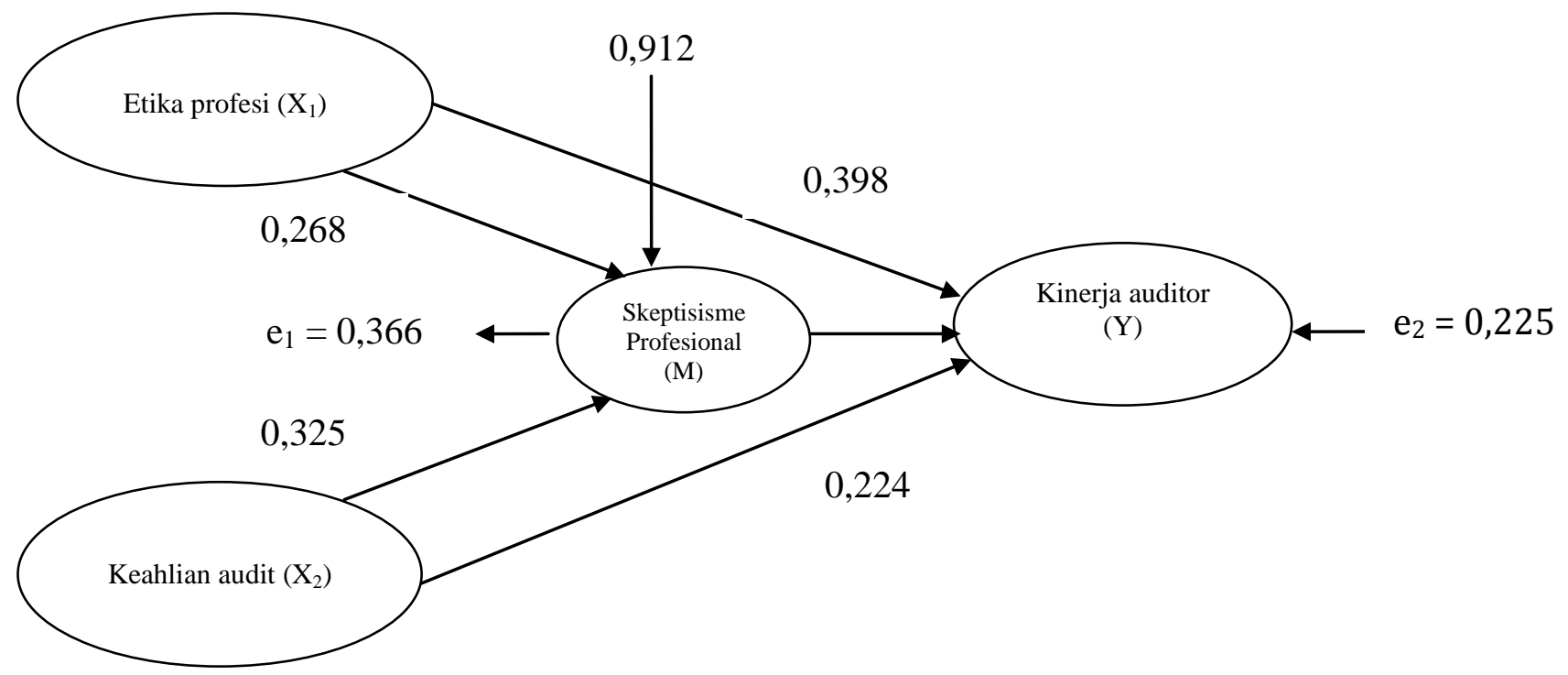

Gambar 1. Model Diagram Jalur Akhir

Sumber: Data diolah, 2017

Gambar 1 menunjukkan nilai koefisien jalur pada model pengaruh etika profesi dan keahlian audit terhadap variabel kinerja auditor melalui skeptisisme professional 
auditor. Berdasarkan informasi pada Gambar 1 diketahui bahwa koefisien jalur pengaruh etika profesi dan keahlian audit terhadap variabel kinerja auditor setelah variabel skeptisisme professional auditor dimasukan ke dalam model bernilai 0,912 tidak bernilai 0, yang berarti skeptisisme professional auditor memediasi pengaruh positif etika profesi dan keahlian audit terhadap kinerja auditor pada Kantor Akuntan Publik Di Bali.

Untuk menguji signifikansi peran mediasi variabel skeptisisme profesional digunakan rumus Sobel. Berdasarkan diagram jalur pengaruh tidak langsung tersebut, maka dapat dihitung Standar error koefisien a dan b ditulis dengan $S_{a}$ dan $S_{b}$, besarnya standar error tidak langsung (indirect effect) $\mathrm{S}_{\mathrm{ab}}$ dihitung dengan rumus berikut ini:

$$
S_{\mathrm{ab}}=\sqrt{b^{2} S_{a}^{2}+a^{2} S_{b}^{2}+S_{a}^{2} S_{b}^{2}}
$$

$$
\begin{aligned}
& \text { Keterangan : } \\
& \begin{array}{ll}
\mathrm{S}_{\mathrm{ab}} \quad=\text { besarnya standar error tidak langsung } \\
\mathrm{S}_{\mathrm{a}} \quad \text { = standar error koefisien a } \\
\mathrm{Sb} \quad=\text { standar error koefisien } \mathrm{b} \\
\mathrm{a} \quad=\text { jalur X terhadap M } \\
\mathrm{b} \quad=\text { jalur M terhadap Y }
\end{array} \\
& \begin{array}{l}
S_{a b}=\sqrt{\left(0,366^{2}\right) 0,068^{2}+\left(0,225^{2}\right) 0,065^{2}+(0,065)^{2}(0,068)^{2}} \\
\mathrm{~S}_{\mathrm{ab}}=0,027
\end{array}
\end{aligned}
$$

Untuk menguji signifikansi pengaruh tidak langsung maka menghitung nilai z dari koefisien ab dengan rumus sebagai berikut:

$$
\mathrm{Z}=\frac{a b}{S_{a b}}
$$


Keterangan:

$\mathrm{S}_{\mathrm{ab}} \quad=$ besarnya standar error tidak langsung

$\mathrm{ab} \quad=$ jalur $\mathrm{X}$ terhadap $\mathrm{M}$ (a) dengan jalur M terhadap $\mathrm{Y}(\mathrm{b})$

$\mathrm{z}=\frac{(0,366)(0,225)}{0,027}$

$z=3,05$

Untuk mengetahui pengambilan keputusan uji hipotesis, maka langkah uji dalam penelitian ini adalah sebagai berikut :

Rumusan Hipotesis

Ho : skeptisisme profesional tidak memediasi pengaruh etika profesi dan keahliang audit terhadap kinerja auditor pada Kantor Akuntan Publik Di Bali.

Hi : skeptisisme profesional memediasi pengaruh etika profesi dan keahliang audit terhadap kinerja auditor pada Kantor Akuntan Publik Di Bali.

Taraf nyata yang digunakan dalam penelitian ini adalah 5 persen. Daerah

kritisnya adalah $\mathrm{z}(0,05)=1,96$.

Kriteria pengujian

$\mathrm{H}_{0}$ diterima dan Hi ditolak apabila $\mathrm{z}$ hitung $\leq \mathrm{z}$ tabel $=1,96$

Ho ditolak dan Hi diterima apabila $\mathrm{z}$ hitung $>\mathrm{z}$ tabel $=1,96$

Menghitung $\mathrm{z}$ hitung

Berdasarkan hasil analisis, maka diperoleh nilai z hitung sebesar 3,05.

Dari hasil perhitungan didapatkan perbandingan nilai z hitung sebesar 3,05 > z tabel sebesar 1,96, maka Ho ditolak dan Hi diterima. Artinya skeptisisme profesional memediasi pengaruh etika profesi dan keahliang audit terhadap kinerja auditor pada Kantor Akuntan Publik Di Bali. 
Menguji nilai koefisien determinasi $\left(\mathrm{R}^{2}\right)$

Berdasarkan perhitungan pengaruh error (Pei), didapatkan hasil pengaruh error ( $\mathrm{Peli}$ ) sebesar 0,366 dan pengaruh error $\left(\mathrm{Pe}_{2}\right)$ sebesar 0,225. Hasil koefisien determinasi total adalah sebagai berikut:

$$
\begin{aligned}
\mathrm{R}_{\mathrm{m}}^{2} & =1-\left(\mathrm{Pe}_{1}\right)^{2}\left(\mathrm{Pe}_{2}\right)^{2} \\
& =1-(0,366)^{2}(0,225)^{2} \\
& =1-(0,133)(0,050) \\
& =1-0,006=0,994
\end{aligned}
$$

Nilai determinasi total sebesar 0,994 mempunyai arti bahwa sebesar 99,4\% variasi kinerja auditor dipengaruhi oleh variabel etika profesi, keahlian audit dan skeptisisme profesional, sedangkan sisanya sebesar 0,6 persen dijelaskan oleh faktor lain yang tidak dimasukkan ke dalam model.

Berdasarkan hasil dari koefisien jalur pada hipotesis penelitian, maka dapat digambarkan hubungan kausal antar variabel skeptisisme profesional memediasi pengaruh etika profesi dan keahliang audit terhadap kinerja auditor pada Kantor Akuntan Publik Di Bali. Perhitungan pengaruh antar variabel dirangkum dalam Tabel 6. 
ISSN: 2302-8556

E-Jurnal Akuntansi Universitas Udayana

Vol.25.2.November (2018): 1448-1480

Tabel 6.

Pengaruh langsung dan pengaruh tidak langsung serta pengaruh total etika profesi $\left(X_{1}\right)$ dan keahlian audit $\left(X_{2}\right)$ pada kinerja auditor $(Y)$ dengan mediasi skeptisisme profesional (M)

\begin{tabular}{llrcc}
\hline Pengaruh Variabel & $\begin{array}{c}\text { Pengaruh } \\
\text { Langsung }\end{array}$ & $\begin{array}{c}\text { Pengaruh Tidak } \\
\text { Langsung M } \\
(\mathbf{p 1} \text { x p3) } \\
(\mathbf{p 2} \text { x p3) }\end{array}$ & Pengaruh Total \\
\hline 1 & $\mathrm{X}_{1} \rightarrow \mathrm{Y}$ & 0,398 & - & 0,398 \\
2 & $\mathrm{X}_{2} \rightarrow \mathrm{Y}$ & 0,224 & - & 0,224 \\
3 & $\mathrm{M} \rightarrow \mathrm{Y}$ & 0,912 & - & 0,912 \\
4 & $\mathrm{X}_{1} \rightarrow \mathrm{M} \rightarrow \mathrm{Y}$ & 0,268 & 0,362 & 0,630 \\
5 & $\mathrm{X}_{2} \rightarrow \mathrm{M} \rightarrow \mathrm{Y}$ & 0,325 & 0,204 & 0,529 \\
\hline
\end{tabular}

Sumber: Data diolah, 2017

Berdasarkan hasil pengujian hipotesis secara statistik pada Tabel 6 dan maka dapat dijelaskan hasil sebagai berikut.

Etika profesi $\left(\mathrm{X}_{1}\right)$ terbukti berpengaruh positif dan signifikan terhadap kinerja auditor (Y), yang ditunjukkan oleh nilai koefisien jalur sebesar 0,398, dengan tingkat signifikansi atau $p$ value $=0,000$, yang berarti sangat signifikan. Koefisien jalur bertanda positif, dapat diartikan bahwa meningkatnya etika profesi seorang auditor akan mendorong terjadinya kinerja auditor yang meningkat, maka hipotesis 1 yang berbunyi, etika profesi berpengaruh positif dan signifikan terhadap kinerja auditor terdukung.

Keahlian audit $\left(\mathrm{X}_{2}\right)$ terbukti berpengaruh positif dan signifikan terhadap kinerja auditor (Y), yang ditunjukkan oleh nilai koefisien jalur sebesar 0,224, dengan tingkat signifikansi atau $p$ value $=0,011$, yang berarti sangat signifikan. Koefisien jalur bertanda positif, dapat diartikan bahwa meningkatnya keahlian seorang auditor secara 
langsung akan meningkatkan kinerja auditor, maka hipotesis 2 yang berbunyi, keahlian audit berpengaruh positif dan signifikan terhadap kinerja auditor terdukung.

Skeptisisme profesional (M) terbukti berpengaruh positif terhadap kinerja auditor (Y), yang ditunjukkan oleh nilai koefisien jalur sebesar 0,912, dengan tingkat signifikansi atau $p$ value $=0,000$, yang berarti sangat signifikan. Koefisien jalur bertanda positif, dapat diartikan bahwa meningkatnya sikap skeptisisme profesional yang dialami oleh seorang auditor mampu meningkatkan kinerja auditor, maka hipotesis 3 yang berbunyi, skeptisisme profesional berpengaruh positif dan signifikan terhadap kinerja auditor terdukung.

Skeptisisme profesional $(\mathrm{M})$ memediasi pengaruh positif etika profesi $\left(\mathrm{X}_{1}\right)$ terhadap kinerja auditor (Y), yang ditunjukkan oleh nilai koefisien jalur sebesar 0,630, dengan tingkat signifikansi atau $p$ value $=0,000$, yang berarti sangat signifikan. Koefisien jalur bertanda positif, dapat diartikan bahwa sikap skeptisisme profesional akan mampu mendorong perilaku seorang audit dalam ber-etika secara profesional sehingga mampu meningkatkan kinerja auditor, maka hipotesis 4 yang berbunyi, skeptisisme profesional memediasi pengaruh positif etika profesi terhadap kinerja auditor terdukung.

Skeptisisme profesional (M) memediasi pengaruh positif keahlian audit $\left(\mathrm{X}_{2}\right)$ terhadap kinerja auditor (Y), yang ditunjukkan oleh nilai koefisien jalur sebesar 0,529, dengan tingkat signifikansi atau $p$ value $=0,000$, yang berarti sangat signifikan. Koefisien jalur bertanda positif, dapat diartikan bahwa sikap skeptisisme profesional akan mampu mendorong sikap keahlian auditor sehingga meningkatkan 
ISSN: 2302-8556

E-Jurnal Akuntansi Universitas Udayana

Vol.25.2.November (2018): 1448-1480

kemampuan untuk meningkatkan kinerja auditor, maka hipotesis 5 yang berbunyi, skeptisisme profesional memediasi pengaruh positif keahlian audit terhadap kinerja auditor terdukung.

Hasil menunjukan bahwa etika profesi berpengaruh positif dan signifikan terhadap kinerja auditor pada Kantor Akuntan Publik Di Bali. Etika yang terjalin diantara anggota tim audit menjadi aktivitas yang sangat fundamental untuk mencapai hasil akhir audit. Istilah profesional berarti tanggung jawab untuk berperilaku lebih dari sekadar memenuhi tanggung jawab secara individu dan ketentuan dalam peraturan dan hukum di masyarakat. Seorang akuntan publik, sebagai seorang profesional, harus menyadari adanya tanggung jawab pada publik, pada klien dan pada sesama rekan praktisi (Nila, 2014).

Hasil penelitian ini sama dengan penelitian Emrinaldi et al. (2014) yang menyatakan jika auditor dapat menjaga keselarasan dalam etika profesinya, ia akan dapat melaksanakan auditnya dengan baik sesuai yang diharuskan dalam kode etik profesi. Ratna (2016) etika memiliki pengaruh positif terhadap kinerja auditor. Nila (2014) variabel etika profesi memiliki pengaruh positif terhadap kinerja auditor. Riris dan Lenny (2016) membuktikan hal yang sama dimana etika profesi memberikan pengaruh positif pada kinerja auditor.

Hasil menunjukan bahwa etika profesi berpengaruh positif dan signifikan terhadap kinerja auditor pada Kantor Akuntan Publik Di Bali. Sukendra et al. (2015) menyatakan teori atribusi dipandang sebagai teori yang dapat mendasari untuk menjelaskan keahlian. Teori tersebut menyatakan, bahwa perilaku ditentukan untuk 
apa orang-orang ingin lakukan (sikap), apa yang mereka pikirkan akan mereka lakukan (aturan-aturan sosial), apa yang mereka bisa lakukan (kebiasaan), dan dengan konsekuensi perilaku yang mereka pikirkan.

Hasil penelitian ini sesuai dengan penelitian Yulia dan Dharma (2017) kinerja seorang audit dipengaruhi oleh keahlian yang dimiliki, semakin luas keahlian seorang auditor maka akan memberikan keyakinan bahwa hasil audit yang lebih baik. Ratna (2016) keahlian memiliki pengaruh positif terhadap kinerja auditor. Tae et al. (2014) variabel keahlian memiliki pengaruh positif terhadap kinerja auditor. Takiah and Zuraidah (2011) membuktikan hal yang sama dimana keahlian memberikan pengaruh positif pada kinerja auditor.

Hasil menunjukan bahwa etika profesi berpengaruh positif dan signifikan terhadap kinerja auditor pada Kantor Akuntan Publik Di Bali. Atribusi teori menjelaskan seorang auditor dalam menggunakan keahliannya dengan cermat untuk merencanakan prosedur audit dan mengevaluasi bukti yang diperoleh, sehingga mampu meningkatkan kinerja auditor (Agus, 2014).

Hasil penelitian ini sesuai dengan penelitian Adnyani et al. (2014) dalam penelitiannya menyatakan skeptisisme profesional memiliki peran penting di dalam meningkatkan kinerja auditor. Tae et al. (2014) variabel skeptisisme professional memiliki pengaruh terhadap kinerja auditor. Pandoyo (2016) membuktikan skeptisisme professional berpengaruh positif dalam meningkatkan kinerja auditor. Berbeda dengan penelitian Ohiokha \& Akhalumeh (2013) skeptisisme professional memiliki pengaruh pada kinerja auditor. 
ISSN: 2302-8556

E-Jurnal Akuntansi Universitas Udayana

Vol.25.2.November (2018): 1448-1480

Hasil uji mediasi menunjukan bahwa skeptisisme profesional mampu memediasi pengaruh positif etika profesi terhadap kinerja auditor pada Kantor Akuntan Publik Di Bali. Teori auditing yang dikemukakan oleh Mautz dan Sharaf (1961) dalam Agus (2014) menjelaskan bahwa seorang auditor harus memiliki sifat kehati-hatian dalam proses pemeriksaannya dan selalu mengutamakan etika profesi, sehingga berperan untuk meningkatkan kinerja seorang auditor.

Hasil penelitian ini sesuai dengan penelitian Adnyani et al. (2014) menjelaskan sikap skeptisisme profesional terhadap kinerja auditor dalam memberikan hasil informasi yang lebih banyak dan lebih signifikan daripada auditor yang memiliki tingkat skeptisisme profesional yang rendah, dan hal ini mengakibatkan auditor memiliki skeptisisme profesional yang tinggi akan lebih dapat mendeteksi adanya fraud karena informasi yang mereka miliki tersebut. Steven and Douglas (2014) skeptisisme memperkuat pengaruh positif etika profesi pada kinerja auditor. Pandoyo (2016) membuktikan skeptisisme professional memoderasi pengaruh etika profesi pada kinerja auditor. Riris dan Lenny, (2016) membuktikan hal yang sama dimana etika profesi memberikan pengaruh positif pada kinerja auditor dengan moderasi skeptisisme professional.

Hasil menunjukan bahwa skeptisisme profesional memediasi pengaruh positif keahlian audit terhadap kinerja auditor pada Kantor Akuntan Publik Di Bali. Teori atribusi menjelaskan tindakan seorang auditor dalam melaksanakan penugasan audit sesuai dengan prosedur sehingga kinerjanya maksimal dan cukup qualified untuk memberikan hasil yang baik terhadap kewajaran sebuah laporan keuangan, seorang 
auditor harus memiliki etika serta keahlian untuk bisa memutuskan atau menentukan sejauhmana tingkat keakuratan dan kebenaran atas bukti-bukti maupun informasi dari klien.

Hasil penelitian ini sesuai dengan penelitian Ratna (2016) keahlian memiliki pengaruh positif terhadap kinerja auditor melalui skeptisisme professional. Tae et al. (2014) variabel skeptisisme professional memperkuat hubungan keahlian terhadap kinerja auditor. Takiah and Zuraidah (2011) membuktikan hal yang sama dimana skeptisisme professional memoderasi variabel keahlian secara positif pada kinerja auditor.

\section{SIMPULAN}

Berlandaskan hasil analisis pada pembahasan bab-bab sebelumnya dapat disimpulkan sebagai berikut : 1). Etika profesi berpengaruh positif dan signifikan pada kinerja auditor pada Kantor Akuntan Publik di Bali; 2). Keahlian audit berpengaruh positif dan signifikan pada kinerja auditor pada Kantor Akuntan Publik di Bali; 3). Skeptisisme profesional berpengaruh positif dan signifikan pada kinerja auditor pada Kantor Akuntan Publik di Bali; 4). Skeptisisme profesional auditor memediasi pengaruh positif etika profesi pada kinerja auditor pada Kantor Akuntan Publik di Bali; 5). Skeptisisme profesional auditor memediasi pengaruh positif keahlian audit pada kinerja auditor pada Kantor Akuntan Publik di Bali.

Berdasarkan kesimpulan maka saran yang dapat disampaikan adalah sebagai berikut: 
ISSN: 2302-8556

E-Jurnal Akuntansi Universitas Udayana

Vol.25.2.November (2018): 1448-1480

Bagi Kantor Akuntan Publik

Hasil penelitian ini diharapkan dapat memberikan kontribusi praktis bagi para praktisi auditing khususnya manajemen KAP agar dapat mempertimbangkan karakteristik yang menyebabkan peningkatan kinerja auditor. Hal yang perlu diperhatikan antara lain seorang auditor harus memiliki sikap etika dan keahlian yang berprofesi sebagi auditor didalam melakasanakan pemeriksaan di tempat klien. Sikap yang dimaksud adalah cekatan, jujur, murah hati dan terbuka di dalam memberikan hasil temua kepada klien sehingga benar bermanfaat bagi kepentingan orang banyak.

Bagi Pengguna Jasa Audit

Bagi perusahaan yang menggunakan jasa audit, harus menjaga keterbukaan dengan memperhatikan ketepatan dalam pelaporan, meningkatkan pelaksanakan aktivitas penilaian dan pemeriksaan atas kebenaran data dan informasi dari sistem dan pengambilan kebijakan yang tepat, sehingga pengawasan dari auditor dalam pengumpulan bukti untuk mendukung temuan audit dapat menghindari perilaku disfungsional untuk mempertahankan keberlangsungan hidup perusahaan.

Bagi peneliti selanjutnya

Persamaan hubungan skeptisisme profesional auditor, etika profesi dan keahlian auditor terhadap kinerja auditor dengan besaran nilai $\mathrm{R}^{2}$ sebesar 99,4\%. Peneliti selanjutnya diharapkan dapat mengambil variabel lainnya seperti moral reasoning, time budget pressure work family conflict dengan menerapkan di lokasi penelitian yang lain seperti perbankan, BUMN, pemerintahan dan lainnya 


\section{REFERENSI}

Agus triyanto, 2014. Pengaruh skeptisisme professional auditor, situasi audit, independensi, etika, keahlian dan pengalaman terhadap ketepatan pemberian opini auditor di Kantor Akuntan Publik di wilayah Yogyakarta. Jurnal Akuntansi Muhamadiyah. 1(3): h: 1-17

Adnyani Nyoman, Anantawikrama Tungga Atmadja dan Trisna Herawati Nyoman, 2014. Pengaruh Skeptisme professional auditor, independensi, dan pengalaman auditor terhadap tanggung jawab auditor dalam mendeteksi kecurangan dan kekeliruan laporan keuangan (Studi Kasus pada Kantor Akuntan Publik (KAP) Wilayah Bali). Jurnal Akuntansi. 2(1): h: 1-11

Alnoprika M. 2015. Pengaruh Kompentensi, Independensi, dan Profesionalisme Auditor Terhadap Kinerja Auditor dengan Etika Profesi Sebagai Variabel Moderating (Studi pada Kantor Akuntan Publik di Pekanbaru, Batam, dan Medan). Jurnal Akuntansi. 2(1): h: 1-15

Azza S.M.Gaballa, Zhou Ning. 2010. An Analytical Study of The Effects of Experience on The Performance of The External Auditor. International Journal Conference on Business and Economics Research. 1(3): h:169-173

Bariyima, BY., David Kiabel, 2012. Auditing and Performance of Government Enterprises: A Nigerian Study. Double Blind Peer Reviewed International Research Journal, 12 (6): h: 1-17

Eluyela Damilola Felix and Ilogho Simon Osiregbemhe. 2016. Audit Standards and Performance of Auditors':Evidence From Nigerian Banking Industry. Journal International Conference on African Development Issues. 3(1): h: 241-244

Emrinaldi Nur DP, Julita dan Dwi Putra Wahyudi, 2014. Pengaruh Etika, Kompetensi, Pengalaman Auditor Dan Situasi Audit Terhadap Ketepatan Pemberian Opini Audit Melalui Pertimbangan Materialitas Dan Skeptisisme Profesional Auditor. Jurnal Ilmiah STIE MDP. 3(2): h: 116-132

Feibe Maria Turangan, David Paul .E. Saerang, Jullie. J. Sondakh. 2016. Pengaruh Skeptisisme Profesional, Kompetensi, dan Independensi Auditor Terhadap Kualitas Pemeriksaan dalam Pengawasan Keuangan Daerah dengan Kepatuhan pada Kode Etik sebagai Variabel Moderating. Jurnal Akuntansi. 4(2): h: 71-88

Ikatan Akuntansi Publik Indonesia. "Kode Etik Profesi Akuntan Publik", Institut Akuntan Publik Indonesia. Jakarta, 2010. 
ISSN: 2302-8556

E-Jurnal Akuntansi Universitas Udayana

Vol.25.2.November (2018): 1448-1480

Rita Anugerah Ria Nelly Sari Rina Mona Frostiana, 2011. The Relationship Between Ethics, Expertise, Audit Experince, Fraud risk assessment and audit situational factors on auditor professional skepticism. Jurnal Repository Akuntasi. 1(1): h: $1-21$

Lisnawati Dewi, 2014. Pengaruh skeptisisme professional auditor, Independensi, Keahlian, Etika Profesi, Pengalaman dan Situasi Audit terhadap ketepatan pemberian opini auditor. Jurnal Akuntansi. pp: 1-25

Meylinda Triyanthi dan Budiartha, Ketut. 2015. Pengaruh Profesionalisme, Etika Profesi, Independensi dan Motivasi kerja Pada Kinerja Internal Auditor ( Studi Kasus Pada Dealer Yamaha di Kota Denpasar). Jurnal Akuntansi Universitas Udayana 10(3): h: 797-809

Musa Adeiza Farouk and Shehu Usman Hassan. 2014. Impact of Audit Quality and Financial Performance of Quoted Cement Firms in Nigeria. International Journal of Accounting and Taxation. 2(2): h: 01-22

Nila Gustia. 2014. Pengaruh Independensi Auditor, Etika Profesi, Komitmen Organisasi dan Gaya Kepemimpinan Terhadap Kinerja Pemerintah (Studi Empiris Pada Auditor Pemerintah di BPKP Perwakilan Sumbar). Jurnal Akuntansi. 1(5): h: 1-23

Ohiokha, Friday Izien \& Akhalumeh, Paul Benign. 2013. Auditing Standards and Auditors Performance: The Nigerian Experince. European Journal of Accounting Auditing and Finance Research. 1(3): h: 15-23

Pandoyo. 2016. The Effect of Auditor Competence, Independence, Audit Experince, Organizational Culture and Leadership Against Auditor Professionalism and Its Implication on Audit Quality. International Journal of Advanced Research. 4(5): h: 1632-1646

Putri, Kompiang Martina Dinata dan I.D.G Dharma Suputra, 2013. Pengaruh independensi, profesionalisme, dan etika profesi terhadap kinerja auditor pada kantor akuntan publik di Bali. Jurnal Akuntansi, 4(1): h: 39-53

Ratna Mappanyuki. 2016. Effects Spiritual Influence of Auditors, Compexity Task, Ethics Auditor and Auditor Expertise on The Performance Auditor Withaccounting Information Systems With Moderating Variabel. (Empirical Study on BPKP Representative Office South Sulawesi). South East Asia Journal of Contemporary Business, Economics and Law. 9(1): h: 28-43 
Riris Rotua Sitorus dan Lenny Wijaya. 2016. Pengaruh Profesionalisme dan Etika Profesi Terhadap Kinerja Auditor dengan Struktur Audit sebagai Pemoderasi. Jurnal Media Studio Ekonomi. 19(2): h: 98-119

Satwika Adhi Nugraha, Ida Bagus., dan Ramantha I Wayan. 2015. Pengaruh Profesionalisme, Etika Profesi dan Pelatihan Auditor terhadap Kinerja Auditor pada Kantor Akuntan Publik di Bali. Jurnal Akuntansi Universitas Udayana 13(3): h: 916-943

Steven M. Glover and Douglas F. Prawitt. 2014. Enhancing Auditor Professional Skepticism: The Professional Skepticism Continuum. International Journal of American Accounting Association. 8(1): h: 1-10

Sukendra, Putu, Gede Adi Yuniarta dan Anantawikrama Tungga Atmadja, 2015. pengaruh skeptisme profesional auditor, pengalaman auditor dan keahlian audit terhadap ketepatan pemberian opini oleh auditor (Studi Empiris pada Inspektorat Kabupaten Buleleng, Kabupaten Bangli dan Kabupaten Karangasem). Jurnal Akuntansi. 3(1): h: 1-12

Syamsuddin, I Made Sudarma, Abdul Hamid Habbe, Mediaty, 2014. The Influences Of Ethics, Independence, And Competence On The Quality Of An Audit Through The Influence Of Professional Skepticism In Bpk Of South Sulawesi, Central Sulawesi And West Sulawesi. Journal of Research in Business and Management. 2(7): h: 08-14

Sugiyono. 2013. Metode Penelitian Bisnis. Bandung: CV. Alfabeta.

Tae G. Ryu, Barbara Uliss, Chul-Young Roh. 2014. The Effect of the SarbanesOxley Act on Auditors' Audit Performance. Journal of Finance and Accountancy. 4(1): h: 1-7

Takiah Mohd Iskandar and Zuraidah Mohd Sanusi. 2011. Assesing The Effects of Self-Efficacy and Task Complexity on Internal Control Audit Judgment. Journal of Finance and Accountancy Asian Academy of Management. 7(1): h: 29-52

Tresno Eka Jaya, Irene, Choirul. 2016. Skepticism, Time Limitation of Audit, Ethics of Professional Accountant and Audit Quality (Case Study in Jakarta, Indonesia). Review of Integrative Business and Economics Research. 5(3): h: 173-182 
ISSN: 2302-8556

E-Jurnal Akuntansi Universitas Udayana

Vol.25.2.November (2018): 1448-1480

Yulia Widiarini, Kadek., dan Dharma Suputra, I.D.G., 2017. Pengaruh Skeptisisme Profesional Auditor, Etika Profesi, Komitmen Profesional Auditor, dan Keahlian Audit terhadap Ketepatan Pemberian Opini oleh Auditor pada Kantor Akuntan Publik di Bali. Jurnal Akuntansi Universitas Udayana. 8(1): h: 88-116 